\title{
A new $\mathrm{CuO}-\mathrm{Fe}_{2} \mathrm{O}_{3}-\mathrm{MCMB}$ conversion anode in high performance lithium-ion battery using
}

\section{$\mathrm{Li}_{1.35} \mathrm{Ni}_{0.48} \mathrm{Fe}_{0.1} \mathrm{Mn}_{1.72} \mathrm{O}_{4}$ spinel cathode}

Daniele Di Lecce ${ }^{\mathrm{a}}$, Roberta Verrelli ${ }^{\mathrm{a}}$, Daniele Campanella ${ }^{\mathrm{b}}$, Vittorio Marangon ${ }^{\mathrm{b}}$ and Jusef Hassoun ${ }^{\mathrm{b},{ }^{*}}$

a Department of Chemistry, Sapienza University of Rome, Piazzale Aldo Moro, 5, 00185, Rome, Italy

${ }^{\mathrm{b}}$ Department of Chemical and Pharmaceutical Sciences, University of Ferrara, Via Fossato di Mortara, 17, 44121, Ferrara, Italy

*Corresponding author: jusef.hassoun@unife.it

\section{Keywords}

Conversion anode; $\mathrm{CuO}-\mathrm{Fe}_{2} \mathrm{O}_{3}-\mathrm{MCMB}$; spinel cathode; $\mathrm{Li}_{1.35} \mathrm{Ni}_{0.48} \mathrm{Fe}_{0.1} \mathrm{Mn}_{1.72} \mathrm{O}_{4}$; lithium-ion battery

\begin{abstract}
Ternary $\mathrm{CuO}-\mathrm{Fe}_{2} \mathrm{O}_{3}-\mathrm{MCMB}$ conversion anode is herein characterized and combined with highvoltage $\mathrm{Li}_{1.35} \mathrm{Ni}_{0.48} \mathrm{Fe}_{0.1} \mathrm{Mn}_{1.72} \mathrm{O}_{4}$ spinel cathode in a lithium-ion battery of relevant performances in terms of cycling stability and rate capability. The $\mathrm{CuO}-\mathrm{Fe}_{2} \mathrm{O}_{3}-\mathrm{MCMB}$ composite is prepared using high-energy milling, i.e., a low-cost pathway which leads to a crystalline structure, and homogeneous submicrometrical morphology revealed by X-ray diffraction and electronic microscopy. The anode reversibly exchanges lithium ions by conversion reactions of $\mathrm{CuO}$ and $\mathrm{Fe}_{2} \mathrm{O}_{3}$, as well as by insertion into MCMB carbon. Electrochemical tests, including impedance spectroscopy, reveal a conductive electrode/electrolyte interface, which enables the anode to achieve a reversible capacity value higher than $500 \mathrm{mAh} \mathrm{g}^{-1}$ when cycled at a current of $120 \mathrm{~mA} \mathrm{~g}^{-1}$. The remarkable stability of the $\mathrm{CuO}-\mathrm{Fe}_{2} \mathrm{O}_{3}-\mathrm{MCMB}$ electrode, and its suitable characteristics in terms of delivered capacity and voltage profile retention, allow its combination in an efficient full lithium-ion cell using high voltage $\mathrm{Li}_{1.35} \mathrm{Ni}_{0.48} \mathrm{Fe}_{0.1} \mathrm{Mn}_{1.72} \mathrm{O}_{4}$

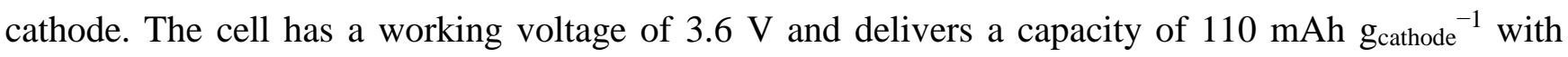
coulombic efficiency above $99 \%$ upon 100 cycles at $148 \mathrm{~mA} \mathrm{~g}_{\text {cathode }^{-1}}$. This relevant performance, rarely
\end{abstract}


achieved by lithium-ion systems using conversion reaction, is due to an excellent cell balance in terms of negative-to-positive ratio, favored by the anode composition and electrochemical features.

\section{Introduction}

Nowadays, lithium-ion batteries R\&D particularly focuses on the development of highperformance electrode materials characterized by enhanced features with respect to conventional ones. ${ }^{[1]}$ In this respect, deep efforts have been devoted to optimizing high-capacity anodes ${ }^{[2-6]}$ and high-voltage cathodes $^{[7-10]}$, with the aim of remarkably increasing the energy content of the battery. Indeed, the energy density of current lithium-ion batteries is considered insufficient to satisfy the challenging requirements of emerging market technologies, such as the electric vehicles. ${ }^{[11]}$ An effective approach to increase the reversible capacity at the anode side may be the use of reaction mechanisms involving a multi-electron process, which differ from the common lithium intercalation. ${ }^{[12-15]}$ Transition metal oxides $\left(\mathrm{M}_{\mathrm{x}} \mathrm{O}_{\mathrm{y}}\right)$ may react with lithium through conversion mechanism to form $\mathrm{Li}_{2} \mathrm{O}$ and metallic $\mathrm{M}$ (oxidation state $=0$ ). This reaction involves multiple electron exchange, thus allowing the Li-conversion electrode to store remarkable capacity with respect to conventional graphite anodes. ${ }^{[16,17]}$ Hence, several oxides have been recently investigated for battery application with promising results. ${ }^{[18-24]}$ Among them, $\mathrm{CuO}$ and $\alpha-\mathrm{Fe}_{2} \mathrm{O}_{3}$ are characterized by a theoretical capacity of 670 and $1007 \mathrm{mAh} \mathrm{g}^{-1}$, respectively, i.e., higher values than the $372 \mathrm{mAh} \mathrm{g}^{-1}$ capacity of conventional graphite carbon. Moreover, these metal oxides are generally cheap, remarkably safe, and environmental compatible. ${ }^{[22,25]}$ Thus, they are suitable candidates for replacing common graphite anodes in advanced lithium-ion batteries with improved energy content. However, anodes based on conversion reaction suffer from large structural and volumetric changes upon the electrochemical process, which have limited to date their application in practical cells. ${ }^{[26-32]}$ Indeed, such a relevant structural change leads to electrode pulverization and loss of electric contact upon prolonged cycling. ${ }^{[33]}$ Furthermore, electrodes operating through conversion reaction typically show high 
irreversible capacity, i.e., ranging between $30 \%$ and $60 \%$, particularly during the first cycles. ${ }^{[33-35]}$ This inefficiency is not only due to irreversible electrochemical decomposition processes at the anode surface but also to low conversion yields caused by active particles disconnections and electrical contact loss upon cycling. Moreover, incomplete de-conversion reaction may generate phases in which the metal assumes a lower valence with respect to the starting compound, thus increasing the cycling inefficiency. ${ }^{[35]}$ The Coulombic efficiency generally increases after the first few cycles and stabilizes upon following cycles. This feature is reasonably caused by the progressive stabilization of the SEI layer formed during the first cycles and to less pronounced electrode structural reorganizations, resulting in increased conversion yields. Recently, the structural variation issue of conversion anodes has been mitigated by adopting nanostructured composite morphologies based on metal oxide active materials and buffer matrixes, such as carbon and metals, suitable for buffering the volume changes and ensure at the same time the electron transport within the electrode. ${ }^{[14,36]}$ Among the several strategies proposed for the synthesis of the nanocomposites, cheap pathways that allow the scaling up from lab-scale to productionscale may lead to the actual diffusion of these appealing electrode materials. ${ }^{[37]}$ Accordingly, high-energy mechanical milling of conversion-type oxides with carbon additives has been suggested as a low-cost and versatile approach for preparing composite anodes. ${ }^{[38,39]}$

Despite the several progresses and optimizations, practical exploitation of high-capacity conversion anodes in full lithium-ion cell configuration still suffers from several issues. The challenging task of moving from half-cell to full-cell requires a proper tuning of the electrode capacity, loading, mass balance, and voltage profile. Missing full-cell balance leads in fact to fast capacity fading, continuous voltage profile modification and, consequently, to short cycle life. These problems are particularly relevant for full-cells using conversion electrodes characterized by high capacity and wide working voltage window, as indeed demonstrated by our previous works in which $\mathrm{CuO}$-carbon ${ }^{[40]}$ and $\mathrm{Fe}_{2} \mathrm{O}_{3}-$ carbon $^{[41]}$ are combined with high voltage spinel cathodes. These cells revealed promising behavior, but 
still limited cycling stability and voltage profile retention. Herein, we modified the conversion anode structure by including both $\mathrm{CuO}$ and $\mathrm{Fe}_{2} \mathrm{O}_{3}$ in its composition, thus allowing voltage profile and capacity suitable for achieving enhanced performance of a full cell combining $\mathrm{CuO}-\mathrm{Fe}_{2} \mathrm{O}_{3}$-carbon composite and $\mathrm{Li}_{1.35} \mathrm{Ni}_{0.48} \mathrm{Fe}_{0.1} \mathrm{Mn}_{1.72} \mathrm{O}_{4}$ spinel cathode. ${ }^{[41]}$ Among various compositions, differing by the amount of the Fe and $\mathrm{Li}$, the $\mathrm{Li}_{1.35} \mathrm{Ni}_{0.48} \mathrm{Fe}_{0.1} \mathrm{Mn}_{1.72} \mathrm{O}_{4}$ revealed the optimal structure (i.e. purity and crystallinity), as well as the best electrochemical properties in terms of delivered capacity, cycling stability and Coulombic efficiency. ${ }^{[41]}$ Therefore, $\mathrm{Li}_{1.35} \mathrm{Ni}_{0.48} \mathrm{Fe}_{0.1} \mathrm{Mn}_{1.72} \mathrm{O}_{4}$ was selected for application in combination with the $\mathrm{CuO}-\mathrm{Fe}_{2} \mathrm{O}_{3}$-carbon composite in full cell, in particular considering literature data indicating the metal substitution of high voltage spinels as a powerful approach for improving the cycling performances. ${ }^{[42-}$ ${ }^{45]}$ Further studies indicated that partial replacement of $\mathrm{Ni}$ and $\mathrm{Mn}$ by bi- and tri-valent ions, such as Fe, $\mathrm{Ru}, \mathrm{Al}, \mathrm{Co}, \mathrm{Cr}$, etc., affects the electrode properties in terms of cation ordering degree, $\mathrm{Mn}^{3+}$ concentration, metal ions dissolution, charge transfer rate and conduction mechanism. Moreover, cationdoping has been indicated to induce morphological and surface modifications by deeply impacting the electrode reactivity towards the electrolyte and its long-term cyclability. ${ }^{[46-48]}$

The $\mathrm{CuO}-\mathrm{Fe}_{2} \mathrm{O}_{3}-\mathrm{MCMB}$ anode, prepared by simple high-energy mechanical milling of $\mathrm{CuO}, \alpha$ $\mathrm{Fe}_{2} \mathrm{O}_{3}$, and meso carbon micro beads (MCMB), is fully characterized in terms of structure, morphology, and electrochemical features in half-cell prior to full-cell study. The new conversion electrode, showing a stable capacity of $500 \mathrm{mAh} \mathrm{g}^{-1}$ in half-cell, leads to a full-cell characterized by a voltage of $3.6 \mathrm{~V}$ and a capacity of $110 \mathrm{mAh} \mathrm{g}_{\text {cathode }}{ }^{-1}$, well retained for over 100 cycles. This is a relevant performance that suggest this system as a suitable and efficient battery prototype. Furthermore, the simple synthesis pathway of the conversion anode and the use of Co-free spinel cathode appear viable strategy for achieving eco-friendly battery of expected low economic impact.

\section{Experimental}


The $\mathrm{CuO}-\mathrm{Fe}_{2} \mathrm{O}_{3}-\mathrm{MCMB}$ composite was prepared by mixing $\mathrm{CuO}$ (Sigma-Aldrich), $\mathrm{Fe}_{2} \mathrm{O}_{3}$ (SigmaAldrich), and meso carbon micro beads (MCMB - Osaka) powders in the 1:1:2 weight ratio through a high-energy spex milling instrument MM 400 (Retsch) at a frequency of $25 \mathrm{~Hz}$. In overall, 40 steps of high energy mechanical milling with duration of 30 minutes each were employed for the preparation of the composite $\mathrm{CuO}-\mathrm{Fe}_{2} \mathrm{O}_{3}-\mathrm{MCMB}$ anode (actual milling time $1200 \mathrm{~min}$ ). Breaks of 10 minutes between the milling steps were employed in order to avoid local heat of the sample holder upon prolonged mechano-chemical treatment, which may induce undesired reactions. Therefore, quantitative recovery of the pristine $\mathrm{CuO}: \mathrm{Fe}_{2} \mathrm{O}_{3}: \mathrm{MCMB}$ weight ratio (i.e., 0.25:0.25:0.5) upon high energy ball milling treatment is expected due to the minimal manipulation of the sample in sealed jars, and the absence of further thermal treatments or weight losses.

The $\mathrm{Li}_{1.35} \mathrm{Ni}_{0.48} \mathrm{Fe}_{0.1} \mathrm{Mn}_{1.72} \mathrm{O}_{4}$ cathode was synthesized according to a previously reported paper. ${ }^{[41]}$ X-ray diffraction (XRD) patterns were acquired by using a Brucker D8 Advance diffractometer equipped with a $\mathrm{Cu} \mathrm{K} \alpha$ source. Rietveld refinement of the XRD patterns was performed by using the MAUD analysis software. ${ }^{[4]}$ Sample morphology and composition were investigated by scanning electron microscopy (SEM), transmission electron microscopy (TEM), and SEM-energy dispersive Xray spectroscopy (EDS), respectively. SEM was carried out through a Zeiss EVO 40 microscope, equipped with a $\mathrm{LaB}_{6}$ thermo-ionic electron gun. SEM-EDS was performed by using a X-ACT, Cambridge Instruments analyzer. Sample preparation for TEM was carried out as following: the powders were suspended in water, sonicated, and deposited onto a Formvar ${ }^{\circledR}$ support film applied to Cu grid. TEM images were taken through a Zeiss EM 910 microscope, equipped with a tungsten thermo-ionic electron gun operating at $100 \mathrm{kV}$.

The electrodes were made by solvent casting of slurries on either $\mathrm{Cu}$ (for the $\mathrm{CuO}-\mathrm{Fe}_{2} \mathrm{O}_{3}-\mathrm{MCMB}$ anode) or $\mathrm{Al}$ (for the $\mathrm{Li}_{1.35} \mathrm{Ni}_{0.48} \mathrm{Fe}_{0.1} \mathrm{Mn}_{1.72} \mathrm{O}_{4}$ cathode) foils. The slurries were prepared by mixing in $\mathrm{N}$ methyl pyrrolidone (Sigma-Aldrich) active material (either $\mathrm{CuO}-\mathrm{Fe}_{2} \mathrm{O}_{3}-\mathrm{MCMB}$ anode or 
$\mathrm{Li}_{1.35} \mathrm{Ni}_{0.48} \mathrm{Fe}_{0.1} \mathrm{Mn}_{1.72} \mathrm{O}_{4}$ cathode), poly(vinylidene fluoride) binder (PVdF 6020, Solef Solvay), and Super P Carbon (Timcal) conductive additive in the ratio $80: 10: 10 \%$ by weight. The slurries were deposited on the electrode support by doctor blade casting, dried overnight under vacuum at $110^{\circ} \mathrm{C}$, and cut in the form of $10 \mathrm{~mm}$ diameter disks. The final electrode mass loading was about 2.0 and $3.5 \mathrm{mg}$ $\mathrm{cm}^{-2}$ for the $\mathrm{CuO}-\mathrm{Fe}_{2} \mathrm{O}_{3}-\mathrm{MCMB}$ anode and the $\mathrm{Li}_{1.35} \mathrm{Ni}_{0.48} \mathrm{Fe}_{0.1} \mathrm{Mn}_{1.72} \mathrm{O}_{4}$ cathode, respectively. All the electrochemical experiments were performed by using an electrolyte solution of $1 \mathrm{M} \mathrm{LiPF}_{6}$ in ethylene carbonate:dimethyl carbonate (EC:DMC) 1:1 by weight (LP30, battery grade, BASF). T-type cells were assembled in Ar-filled glovebox by stacking anode, Whatman separator soaked by the electrolyte, and cathode.

Cyclic voltammetry (CV) tests were carried out through a VersaSTAT MC Princeton Applied Research (PAR) analyzer on three-electrode cells employing two lithium disks as counter and reference electrodes. $\mathrm{CV}$ on $\mathrm{CuO}-\mathrm{Fe}_{2} \mathrm{O}_{3}-\mathrm{MCMB}$ was performed at a scan rate of $0.1 \mathrm{mV} \mathrm{s}^{-1}$ within the $2.7-0.01 \mathrm{~V} \mathrm{vs.} \mathrm{Li}^{+} / \mathrm{Li}$ potential range. $\mathrm{CV}$ on $\mathrm{Li}_{1.35} \mathrm{Ni}_{0.48} \mathrm{Fe}_{0.1} \mathrm{Mn}_{1.72} \mathrm{O}_{4}$ was performed at a scan rate of $0.1 \mathrm{mV} \mathrm{s}^{-1}$ within the 5 $-3.5 \mathrm{~V}$ vs. $\mathrm{Li}^{+} / \mathrm{Li}$ potential range. Galvanostatic cycling experiments were carried out on two-electrode cells through a MACCOR series 4000 battery test system. Cycling test of $\mathrm{CuO}-\mathrm{Fe}_{2} \mathrm{O}_{3}-\mathrm{MCMB}$ in lithium half-cell was performed within the $3-0.01 \mathrm{~V}$ voltage range at $\mathrm{C} / 5$ rate $\left(1 \mathrm{C}=606 \mathrm{~mA} \mathrm{~g}^{-1}\right)$; electrochemical impedance spectra (EIS) were recorded throughout the cycling test at open circuit voltage $(\mathrm{OCV})$ and at the $1^{\text {st }}, 10^{\text {th }}$, and $50^{\text {th }}$ cycles. The EIS tests were carried out through a VersaSTAT MC Princeton Applied Research (PAR) analyzer by applying a $10 \mathrm{mV}$ amplitude signal in the $500 \mathrm{kHz}$ $-20 \mathrm{mHz}$ frequency range. The cell used for the cycling/EIS experiment on $\mathrm{CuO}-\mathrm{Fe}_{2} \mathrm{O}_{3}-\mathrm{MCMB}$ had three-electrode configuration with a lithium probe as reference electrode and a lithium disk as counter electrode; the lithium probe reference was used only for EIS. The impedance spectra were analyzed by nonlinear least squares (NLLS) method by using the Boukamp software. ${ }^{[50]}$ Rate capability test of CuO$\mathrm{Fe}_{2} \mathrm{O}_{3}-\mathrm{MCMB}$ in lithium half-cell was performed within the $3-0.01 \mathrm{~V}$ voltage range at $\mathrm{C} / 5, \mathrm{C} / 3, \mathrm{C} / 2$, 
$1 \mathrm{C}, 2 \mathrm{C}$, and $5 \mathrm{C}$ rates $\left(1 \mathrm{C}=606 \mathrm{~mA} \mathrm{~g}^{-1}\right)$. Cycling test of $\mathrm{Li}_{1.35} \mathrm{Ni}_{0.48} \mathrm{Fe}_{0.1} \mathrm{Mn}_{1.72} \mathrm{O}_{4}$ in lithium half-cell was performed within the $5-3 \mathrm{~V}$ voltage range at $1 \mathrm{C}$ rate $(1 \mathrm{C}$ is referred to the electrochemical reaction of the benchmark spinel with composition $\mathrm{LiNi}_{0.5} \mathrm{Mn}_{1.5} \mathrm{O}_{4}$, i.e., $1 \mathrm{C}=148 \mathrm{~mA} \mathrm{~g}^{-1}$ ). Cycling test of the CuO$\mathrm{Fe}_{2} \mathrm{O}_{3}-\mathrm{MCMB} / \mathrm{Li}_{1.35} \mathrm{Ni}_{0.48} \mathrm{Fe}_{0.1} \mathrm{Mn}_{1.72} \mathrm{O}_{4}$ full-cell was carried out within the $4.9-1.6 \mathrm{~V}$ voltage range at $1 \mathrm{C}$ rate with respect to the cathode (i.e., $148 \mathrm{~mA} \mathrm{~g}_{\text {cathode }}{ }^{-1}$ ). Prior to use in full cell the anode has been activated by pre-lithiated by cycling in half cell (3 cycles at C/5) in order to hold the anode/cathode balance. The electrodes loading and anode/cathode mass ratio of the full lithium-ion cell were selected in order to achieve the maximum capacity exchanged by the positive electrode. Therefore, the full-cell was cathode limited by setting up a negative to positive ratio of 2.5 , obtained basing on the reversible capacity of anode $\left(500 \mathrm{mAh} \mathrm{g}^{-1}\right)$ and cathode $\left(110 \mathrm{mAh} \mathrm{g}^{-1}\right)$ and the anode/cathode mass ratio of approximately 1:2. All the electrochemical tests were performed at $23^{\circ} \mathrm{C}$.

\section{Results and discussion}

The structural features of $\mathrm{CuO}-\mathrm{Fe}_{2} \mathrm{O}_{3}-\mathrm{MCMB}$ are reported in Fig. 1, which shows a comparison between the XRD patterns of the electrode powder with the reference powder diffraction files (PDF) of $\mathrm{CuO}$ (PDF \# 80-1916), $\mathrm{Fe}_{2} \mathrm{O}_{3}$ (PDF\# 87-1165), and graphite carbon (PDF \# 75-1621) phases. Peak width evaluation suggests lower crystallite grain size for $\mathrm{CuO}$ with respect to $\mathrm{Fe}_{2} \mathrm{O}_{3}$ : indeed, the former exhibits lower and broader XRD signals than the latter. Furthermore, XRD indicates that carbon has partially graphitic structure. Previous studies of composite materials based on conversion-type compounds and carbon prepared by high-energy mechanical milling revealed significant decrease of the crystallinity degree by increasing the treatment time. ${ }^{[38,39,51]}$ The ball milling induces also a progressive decrease of sample particle size with concomitant formation of micrometric aggregates consisting of nanometric oxide particles embedded within the carbon matrix. This particular morphology may actually mitigate the remarkable particle rearrangement and volume stress ${ }^{[52]}$ related to the conversion reaction. ${ }^{[21]}$ 
Figure 1

The electrode morphology plays a crucial role in the lithium exchange ability of conversion-type anodes. ${ }^{[36]}$ Hence, we have studied the $\mathrm{CuO}-\mathrm{Fe}_{2} \mathrm{O}_{3}-\mathrm{MCMB}$ composite by coupling electron microscopy techniques and EDS, as shown in Fig. 2. The SEM image (Fig. 2a) reveals that the ternary composite powder is formed by micrometric aggregates of heterogeneous size, having maximum dimension of few micrometers, as further shown by SEM magnification (inset of Fig. 2a). Meanwhile, the atomic distribution of $\mathrm{C}, \mathrm{Fe}$, and $\mathrm{Cu}$ over the particles, shown by EDS mapping (Fig. 2b), confirms actual dispersion of the related compounds throughout the milling process. Moreover, the more homogeneous distribution of $\mathrm{Fe}$ atoms with respect to $\mathrm{Cu}$ within the sample (insets of Fig. 2b) suggests smaller size for the $\mathrm{Fe}_{2} \mathrm{O}_{3}$ particles with respect to the $\mathrm{CuO}$ ones. Bearing in mind the XRD results, which show higher peak broadening for $\mathrm{CuO}$ with respect to $\mathrm{Fe}_{2} \mathrm{O}_{3}$, we suppose that the $\mathrm{CuO}-\mathrm{Fe}_{2} \mathrm{O}_{3}-\mathrm{MCMB}$ sample is formed by bigger $\mathrm{CuO}$ particles having low crystallinity degree and smaller $\mathrm{Fe}_{2} \mathrm{O}_{3}$ crystals. Furthermore, TEM images of Fig. 2c-d reveal that the micrometric composite aggregates are formed by oxide subparticles with maximum size of few hundreds of nanometers (high-contrast particles in the figure) embedded within the carbon matrix (low-contrast particles in the figure). This particular morphology is expected to reflect into optimized electrochemical performance of the electrode in lithium cell. Carbon matrix in which transition metal oxide particles are finely dispersed may actually buffer the volume changes related to the conversion reaction, ${ }^{[51]}$ prevent possible loss of electric contact within the electrode throughout cycling, and ensure at the same time fast $\mathrm{Li}^{+}$and electron transport. ${ }^{[53,54]}$ In summary, the microscopy characterization demonstrates that the easily scalable high-energy milling treatment can produce a composite nanostructured material with suitable features for application in lithium-ion cells. ${ }^{[38]}$

Figure 2

The electrochemical features of the composite anode have been evaluated by combining voltammetry and galvanostatic cycling (Fig. 3) as well as by impedance spectroscopy technique (Fig. 4). 
Fig. 3a shows the cyclic voltammetry response of a three-electrode lithium cell with $\mathrm{CuO}-\mathrm{Fe}_{2} \mathrm{O}_{3}-\mathrm{MCMB}$ working electrode. According to previous reports on composite conversion anodes, ${ }^{[38,41]}$ the first cycle evidences irreversible processes related to the SEI formation and structural rearrangements within the material, besides the reversible lithiation of $\mathrm{CuO}, \mathrm{Fe}_{2} \mathrm{O}_{3}$, and carbon matrix. Thus, the first cathodic scan reveals two peaks at 1.1 and $0.7 \mathrm{~V}$ vs. $\mathrm{Li}^{+} / \mathrm{Li}$, which reflect the reduction of $\mathrm{CuO}^{[38]}$ and $\mathrm{Fe}_{2} \mathrm{O}_{3}{ }^{[41]}$ to $\mathrm{Cu}$, $\mathrm{Fe}$, and $\mathrm{Li}_{2} \mathrm{O}$, followed by a broad signal below $0.4 \mathrm{~V}$ vs. $\mathrm{Li}^{+} / \mathrm{Li}$ suggesting lithium insertion into carbon. ${ }^{[55]}$ Carbon delithiation process at about $0.3 \mathrm{~V} \mathrm{vs.} \mathrm{Li}^{+} / \mathrm{Li}$, and de-conversion reactions above $1 \mathrm{~V}$ vs. $\mathrm{Li}^{+} / \mathrm{Li}$ are observed throughout the first anodic scan. The $\mathrm{CV}$ profile stabilizes by subsequent cycles and reveals reversible lithium conversion within the $0.7-2.5 \mathrm{~V}$ vs. $\mathrm{Li}^{+} / \mathrm{Li}$ potential range and lithium insertion into the carbon matrix below $0.3 \mathrm{~V}$ vs. $\mathrm{Li}^{+} / \mathrm{Li}$. Previous studies of the reaction mechanism concerning conversion-type anodes have evidenced a multistep process evolving within wide potential range, ${ }^{[26-28,30,31]}$ leading to remarkable reorganization upon the first reduction until formation of metallic nano-particles embedded into a $\mathrm{Li}_{2} \mathrm{O}$ matrix. ${ }^{[33]}$ Indeed, in situ TEM observations have revealed that CuO-based electrodes undergo reduction during the first discharge by formation of intermediate lithiated phases, involving $\left[\mathrm{Cu}_{1-\mathrm{x}}{ }^{\mathrm{II}} \mathrm{Cu}_{\mathrm{x}}{ }_{\mathrm{T}}^{\mathrm{T}} \mathrm{O}_{1-\mathrm{x} / 2}\right.$ solid solution, transition to $\mathrm{Cu}_{2} \mathrm{O}$ phase, as well as conversion to $\mathrm{Cu}$ and $\mathrm{Li}_{2} \mathrm{O} .{ }^{[26-28]}$ This process may cause partial reversibility and remarkable particle size change; afterwards, the electrode structure stabilizes throughout cycling. ${ }^{[26-29]}$ Similarly, electron microscopy, XRD, and X-ray photoelectron spectroscopy studies have shown that $\mathrm{Fe}_{2} \mathrm{O}_{3}$ exchanges lithium ions through insertion followed by conversion to metallic $\mathrm{Fe}$ embedded within a $\mathrm{Li}_{2} \mathrm{O}$ matrix, leading to significant electrode swelling upon lithiation. ${ }^{[30-32]}$ In Summary, the $\mathrm{CuO}-\mathrm{Fe}_{2} \mathrm{O}_{3}-\mathrm{MCMB}$ electrode reflects in lithium cell the complex, multi-step conversion reactions of the $\mathrm{CuO}$ and $\mathrm{Fe}_{2} \mathrm{O}_{3}$ leading to the formation of metallic $\mathrm{Cu}$ and $\mathrm{Fe}$ dispersed within a $\mathrm{Li}_{2} \mathrm{O}$ matrix, as well as the lithium insertion into MCMB matrix, as schematized below:

\section{i) $\mathrm{Li} / \mathrm{CuO}$ conversion}


$\mathrm{CuO}+x \mathrm{Li}^{+}+x \mathrm{e}^{-} \rightarrow \mathrm{Li}_{x} \mathrm{CuO}(0<x<1)$

$\mathrm{LiCuO}+(y) \mathrm{Li}^{+}+(\mathrm{y}) \mathrm{e}^{-} \rightarrow \mathrm{Li}_{1+\mathrm{y}} \mathrm{CuO}(0<y<1)$, with progressive formation of $\mathrm{Cu}+\mathrm{Li}_{2} \mathrm{O}$ for $\mathrm{y}=1$

ii) $\mathrm{Li} / \mathrm{Fe}_{2} \mathrm{O}_{3}$ conversion

$\mathrm{Fe}_{2} \mathrm{O}_{3}+x \mathrm{Li}^{+}+x \mathrm{e}^{-} \rightarrow \mathrm{Li}_{x} \mathrm{Fe}_{2} \mathrm{O}_{3} 0 \leq x \leq 1$

$\mathrm{Li}_{x} \mathrm{Fe}_{2} \mathrm{O}_{3}+y \mathrm{Li}^{+}+y \mathrm{e}^{-} \rightarrow \mathrm{Li}_{x+y} \mathrm{Fe}_{2} \mathrm{O}_{3} 0 \leq y \leq 1$

$\mathrm{Li}_{2} \mathrm{Fe}_{2} \mathrm{O}_{3}+4 \mathrm{Li}^{+}+4 \mathrm{e}^{-} \rightarrow 3 \mathrm{Li}_{2} \mathrm{O}+2 \mathrm{Fe}$

iii) Li/MCMB insertion:

$\mathrm{C}+x \mathrm{Li}^{+}+x \mathrm{e}^{-} \rightarrow \mathrm{Li}_{x} \mathrm{C}$

According to theoretical reaction of $\mathrm{CuO}, \mathrm{Fe}_{2} \mathrm{O}_{3}$, and $\mathrm{MCMB}$ with lithium and to the ratio of the pristine materials, the $\mathrm{CuO}-\mathrm{Fe}_{2} \mathrm{O}_{3}-\mathrm{MCMB}$ electrode capacity is evaluated to be of $606 \mathrm{mAh}^{-1}$. This value takes into account: (i) full conversion of $\mathrm{CuO}$ and $\mathrm{Fe}_{2} \mathrm{O}_{3}$ leading to capacity of 670 and $1006 \mathrm{mAh}$ $\mathrm{g}^{-1}$, respectively, (ii) the theoretical capacity of graphite carbon (i.e., $374 \mathrm{mAh} \mathrm{g}^{-1}$ ), and (iii) the weight ratio of the components $\left(\mathrm{CuO}: \mathrm{Fe}_{2} \mathrm{O}_{3}: \mathrm{MCMB}=1: 1: 2\right.$, experimental section). However, possible deviation of the actual value from the theoretical one is reasonably expected due to the above mentioned partial reversibility of the conversion reaction. The galvanostatic cycling voltage profiles of $\mathrm{CuO}-\mathrm{Fe}_{2} \mathrm{O}_{3}-\mathrm{MCMB}$ in lithium half-cell at $\mathrm{C} / 5$ rate (Fig. 3b) are in agreement with the voltammetry results. Indeed, the first discharge profile (inset of Fig. 3b) reveals two voltage plateaus at about 1.2 and $0.8 \mathrm{~V}$ related to the $\mathrm{CuO}^{[38]}$ and $\mathrm{Fe}_{2} \mathrm{O}_{3}{ }^{[41]}$ conversion processes, as well as the electrochemical insertion of lithium ions into carbon at about $0.1 \mathrm{~V} .{ }^{[55]}$ The subsequent charge occurs through plateau centered at 0.1 and $1.7 \mathrm{~V}$, ascribed to the delithiation of carbon ${ }^{[55]}$ and to the reverse de-conversion to the transition metal oxides, ${ }^{[38,41]}$ respectively. The first cycle shows high irreversible capacity, partially attributed to SEI formation as well as to the above discussed intrinsic irreversibility of the conversion redox process. ${ }^{[32]}$ Subsequent cycles evidence limited voltage profile changes, reversible capacity ranging from 500 to 580 
$\mathrm{mAh} \mathrm{g}^{-1}$ stable for over 100 charge/discharge cycles and coulombic efficiency above $95 \%$ (Fig. 3b,c). The observed hysteresis between the discharge and charge potentials represents one of the main issues of anodes reacting through conversion mechanism. This phenomenon has been attributed in literature ${ }^{[34]}$ to intrinsic difference between the electrode reduction and oxidation reaction pathways. Since different electrode/electrolytes interphases and different electrochemical equilibrium occur upon discharge and charge, the conversion and de-conversion potentials consistently differ from each other. This asymmetry arises from the inherent diffusion limits of additional species $(\mathrm{M}$ and $\mathrm{X})$ along with $\mathrm{Li}^{+}$. Although more pronounced during the first cycle, large voltage hysteresis is observed within the entire conversion electrode cycle life and originates significant cell round-trip inefficiency. This severe issue may be reasonably mitigated, but not completely avoided, by a proper selection of the conversion materials and by minimizing the diffusion lengths through optimal electrode morphologies and architectures, as attempted in this study by the preparation of a composite, sub-micrometric composite material. The rate capability test reported in Fig. 3d, and corresponding voltage profile Fig. S1 of the Supporting Information, show reversible capacity of 520, 470, 440, 340, 250, and $160 \mathrm{mAh} \mathrm{g}^{-1}$ at C/5, C/3, C/2, 1C, $2 \mathrm{C}$, and $5 \mathrm{C}\left(1 \mathrm{C}=606 \mathrm{mAh} \mathrm{g}^{-1}\right)$ and the expected polarization increase by raising the current. It is noteworthy that the ternary $\mathrm{CuO}-\mathrm{Fe}_{2} \mathrm{O}_{3}-\mathrm{MCMB}$ anode exhibits higher delivered capacity, cycling stability, first cycle efficiency and rate capability with respect to the binary CuO-MCMB previously characterized by our group. ${ }^{[38]}$ As compared with binary $\mathrm{Fe}_{2} \mathrm{O}_{3}-\mathrm{MCMB}^{[41]}$, the ternary anode here presented shows similar electrochemical properties in terms of reversibility and stability, despite the lower capacity and the higher operating voltage due to the presence of $\mathrm{CuO}$. Therefore, the performances of the $\mathrm{CuO}-\mathrm{Fe}_{2} \mathrm{O}_{3}-\mathrm{MCMB}$ are considered suitable for application as anode in lithium-ion cells, as indeed shown by the following paragraphs.

Figure 3 
Further investigation of the electrode/electrolyte interface has been carried out by electrochemical impedance spectroscopy (EIS) upon cycling. EIS has been performed on the lithium half-cell of Fig. 3b and $\mathrm{c}$, at the OCV condition as well as upon $1^{\text {st }}, 10^{\text {th }}$, and $50^{\text {th }}$ cycle. Three-electrode arrangement consisting of $\mathrm{CuO}-\mathrm{Fe}_{2} \mathrm{O}_{3}-\mathrm{MCMB}$ working electrode, a lithium disk counter electrode and a lithium reference probe was used for the test. This configuration allows both two-electrode galvanostatic cycling and the study of the $\mathrm{CuO}-\mathrm{Fe}_{2} \mathrm{O}_{3}-\mathrm{MCMB} /$ electrolyte interface by impedance tests using lithium reference electrode (see the experimental section for further details). The Nyquist plots of Fig. 4 show the experimental data and those simulated by NLLS analysis ${ }^{[56]}$ using the equivalent circuits of Fig. S2 in the Supporting Information. The theoretical circuits accurately describe the electrochemical system, as suggested by the overlapping of the simulated spectra with the experimental data (Fig. 4). The impedance response at the OCV shown in Fig. 4a is simulated by considering the equivalent circuit of Fig. S2a (Supporting Information) with contributions of ohmic electrolyte resistance calculated as intercept at the high frequency $\left(\mathrm{R}_{\mathrm{e}}\right)$, resistance and constant phase element related to a native film on the electrode surface represented by the middle-high frequency semicircle ( $R_{i}$ and $C P E_{i}$, respectively) and a geometrical capacitance of the cell revealed by the low-frequency vertical line $\left(\mathrm{Q}_{\mathrm{g}}\right)$. Cell operation remarkably changes the EIS response (Fig. 4b-d), analyzed by employing the equivalent circuits reported in Fig. S2b (see the Supporting Information). Besides electrolyte resistance $\left(\mathrm{R}_{\mathrm{e}}\right)$, the Nyquist plots upon cycling exhibit two partially overlapped semicircles ascribed to SEI film at high-frequency $\left(\mathrm{R}_{\mathrm{film}}\right.$, $\left.\mathrm{CPE}_{\text {film }}\right)$ and charge transfer within the electrode/electrolyte interface at middle frequency $\left(\mathrm{R}_{\mathrm{ct}}, \mathrm{CPE} \mathrm{dl}_{\mathrm{dl}}\right),{ }^{[57]}$ as well as a low-frequency line having slope of approximately $45^{\circ}$ related to the Warburg-type semiinfinite diffusion within the electrode $(\mathrm{W}) .{ }^{[58,59]}$ The low and stable overall values of the interface resistances $\left(\mathrm{R}_{\mathrm{i}}\right)$ calculated in Table 1 suggest the formation of a conductive and stable electrode/electrolyte interphase upon cycling. Indeed, the table reveals OCV resistance values of the native passivation layer below $30 \Omega$. After the $1^{\text {st }}$ cycle, the interface resistance decreases to a value as 
low as $14 \Omega$, due to partial dissolution of the $\mathrm{SEI},{ }^{[60]}$ and stabilizes at about $11 \Omega$ over the subsequent galvanostatic cycles, thus justifying the enhanced cycling trend observed for $\mathrm{CuO}-\mathrm{Fe}_{2} \mathrm{O}_{3}-\mathrm{MCMB}$ electrode (Fig. 3b, c). The evolution upon cycling of the SEI film on $\mathrm{CuO}-\mathrm{Fe}_{2} \mathrm{O}_{3}-\mathrm{MCMB}$ surface observed by EIS fully reflects characteristic trends of the films formed at the $\mathrm{CuO}, \mathrm{Fe}_{2} \mathrm{O}_{3}$ and $\mathrm{MCMB}$ materials, widely described in literature. Indeed, XPS and AFM data have revealed the formation of a thick SEI layer for $\mathrm{CuO}$ thin film anode in cell using an electrolyte based on $\mathrm{LiPF}_{6}$ salt and carbonate solvent. ${ }^{[61]}$ The above study indicated the formation at the anode surface of a SEI composed by an inorganic inner $\mathrm{LiF}$-rich layer rich and an outer layer of $\mathrm{Li}_{2} \mathrm{CO}_{3}$ and polymers/oligomers during the first lithiation process, partial dissolution of outer layer without significant variations of the inner one during delithiation, and growing of a polymeric, organic layer with reversible formation/dissolution of nodules by subsequent charge/discharge cycles. Further studies have demonstrated SEI film formation and dissolution at the surface of anodes reacting through conversion mechanism upon cycling, e.g., $\mathrm{CuO}{ }^{[62]}$ $\mathrm{Fe}_{2} \mathrm{O}_{3},{ }^{[63]}$ and $\mathrm{Cr}_{2} \mathrm{O}_{3},{ }^{[64]}$ and growth upon cycling of a layer mainly consisting of lithium alkyl-carbonates, $\mathrm{RCO}_{2} \mathrm{Li}$, $\mathrm{ROLi}$, oligomers, $\mathrm{Li}_{2} \mathrm{CO}_{3}$ and $\mathrm{LiF}$ for carbonaceous materials in electrolytes composed by $\mathrm{LiPF}_{6}$ salt and carbonate solvents. ${ }^{[65]}$

\section{Figure 4}

The $\mathrm{CuO}-\mathrm{Fe}_{2} \mathrm{O}_{3}-\mathrm{MCMB}$ electrode has been therefore employed as the anode in a full lithium-ion cell using a high-voltage $\mathrm{Li}_{1.35} \mathrm{Ni}_{0.48} \mathrm{Fe}_{0.1} \mathrm{Mn}_{1.72} \mathrm{O}_{4}$ cathode. ${ }^{[41]}$ Fig. S3a in the Supporting Information reports the XRD patterns of the $\mathrm{Li}_{1.35} \mathrm{Ni}_{0.48} \mathrm{Fe}_{0.1} \mathrm{Mn}_{1.72} \mathrm{O}_{4}$ powder, and reveals a single $\mathrm{Fd} \overline{3} \mathrm{~m}$ phase with no significant impurity and refined cell parameter of $8.1941 \pm 0.0002 \AA$. Moreover, SEM of Fig. S3b indicates that the cathode material is formed by aggregates of sub-micrometric and micrometric octahedrons.

The cyclic voltammetry curve of the $\mathrm{Li}_{1.35} \mathrm{Ni}_{0.48} \mathrm{Fe}_{0.1} \mathrm{Mn}_{1.72} \mathrm{O}_{4}$ cathode, reported in Fig. S4 of the Supporting Information, reveals highly reversible electrochemical processes related to the $\mathrm{Ni}^{4+} / \mathrm{Ni}^{3+}$ and 
$\mathrm{Ni}^{3+} / \mathrm{Ni}^{2+}$ redox couples, with peaks centered at 4.8 and $4.6 \mathrm{~V} \mathrm{vs} . \mathrm{Li}^{+} / \mathrm{Li}$, respectively, as well as to the $\mathrm{Mn}^{3+} / \mathrm{Mn}^{4+}$ couple in the $4.1 \mathrm{~V}$ potential region. Furthermore, the $\mathrm{Li}_{1.35} \mathrm{Ni}_{0.48} \mathrm{Fe}_{0.1} \mathrm{Mn}_{1.72} \mathrm{O}_{4}$ cathode has been studied by galvanostatic cycling in lithium half-cell at $1 \mathrm{C}$ rate $\left(148 \mathrm{~mA} \mathrm{~g}^{-1}\right)$. The voltage profile of the cathode shown in Fig. 5a agrees with CV tests and evidences the sloping plateau centered at $4.1 \mathrm{~V}$ due to the $\mathrm{Mn}^{4+} / \mathrm{Mn}^{3+}$ redox processes as well as the two adjacent plateaus due to the $\mathrm{Ni}^{4+} / \mathrm{Ni}^{3+}$ and $\mathrm{Ni}^{3+} / \mathrm{Ni}^{2+}$ couples. ${ }^{[41]}$ After a slightly different initial cycle due to SEI film formation at the higher voltage values ${ }^{[41]}$ the excellent overlapping of the voltage profiles confirms the highly reversible character of $\mathrm{Li}_{1.35} \mathrm{Ni}_{0.48} \mathrm{Fe}_{0.1} \mathrm{Mn}_{1.72} \mathrm{O}_{4}$ electrochemical process already suggested by voltammetry (compare Fig. 5a and Fig. S4). The cycling trend of the cathode in lithium half-cell reported in Fig. 5b reveals remarkably stable performance, with reversible capacity of about $110 \mathrm{mAh} \mathrm{g}^{-1}$ and coulombic efficiency above $99 \%$ over 200 cycles of charge and discharge at current rate of $1 \mathrm{C}\left(148 \mathrm{~mA} \mathrm{~g}^{-1}\right)$.

The panels $\mathrm{c}$ and $\mathrm{d}$ of Fig. 5 show the galvanostatic cycling results of the full $\mathrm{CuO}-\mathrm{Fe}_{2} \mathrm{O}_{3}-$ $\mathrm{MCMB} / \mathrm{Li}_{1.35} \mathrm{Ni}_{0.48} \mathrm{Fe}_{0.1} \mathrm{Mn}_{1.72} \mathrm{O}_{4}$ lithium-ion cell. The full cell was limited to the cathode capacity by using excess of anode material in order to ensure the balance between the electrodes upon prolonged cycling. Indeed, the anode excess mitigates the effect of irreversible parasitic reactions at the electrode/electrolyte interface, and almost completely avoids possible Li deposition upon charge, which may represent a serious safety issue. Prior to use in full cell, the excess of anode capacity, which may completely avoid the cell balance, has been mitigated by anode pre-lithiation, i.e., a process consisting of few cycles in half cell until the anode reaches its steady state, stable working conditions and the desired cell balance (see experimental section). This procedure also allows to limit the irreversible consumption of active $\mathrm{Li}^{+}$at the cathode side due to irreversible SEI formation on the anode in the full cell configuration, thus ensuring high reversibility and coulombic efficiency of the battery even from the first cycles. Of course, anode pre-lithiation is not attractive from an application perspective, since it would increase the industrial costs of the battery production; however, it represents a useful strategy to reduce 
the anode irreversibility for a laboratory scale battery prototype as the one reported in this study. During the initial few cycles, the cell undergoes the expected stabilization of the voltage profile (Fig. S5 of the Supporting Information) due to the electrode/electrolyte interface formation as well as to the above discussed structural reorganization of $\mathrm{CuO}-\mathrm{Fe}_{2} \mathrm{O}_{3}-\mathrm{MCMB}$ anode. ${ }^{[38,41]}$ This process is also evidenced by the increase of the charge-discharge coulombic efficiency from $84 \%$ at the $1^{\text {st }}$ cycle up to $99 \%$ at the $30^{\text {th }}$ cycle, and corresponding increase of the reversible capacity from 100 to $110 \mathrm{mAh} \mathrm{g}^{-1}$ (Fig. 5d). The fullcell exhibits steady-state voltage profiles centered at about $3.6 \mathrm{~V}$ (Fig. 5c), which reflect combination of the multistep reaction of the conversion-type anode and the redox processes characteristic of the spinel cathode. Remarkably, the $\mathrm{CuO}-\mathrm{Fe}_{2} \mathrm{O}_{3}-\mathrm{MCMB} / \mathrm{Li}_{1.35} \mathrm{Ni}_{0.48} \mathrm{Fe}_{0.1} \mathrm{Mn}_{1.72} \mathrm{O}_{4}$ full-cell shows a very stable cycling trend upon 100 charge-discharge cycles (Fig. 5d), with a capacity retention and efficiency approaching $100 \%$ over the whole galvanostatic test. This excellent behavior, rarely observed for new cell configurations alternative to commercial ones, may be attributed to: $i$ ) optimized electrodes structure and morphology leading to remarkable stability of their electrode/electrolyte interface; ii) suitable electrode characteristics in terms voltage profile and delivered capacity; iii) proper cell balance in terms of negative-to-positive ratio and suitable operating conditions. However, the $\mathrm{CuO}-\mathrm{Fe}_{2} \mathrm{O}_{3}$ $\mathrm{MCMB} / \mathrm{Li}_{1.35} \mathrm{Ni}_{0.48} \mathrm{Fe}_{0.1} \mathrm{Mn}_{1.72} \mathrm{O}_{4}$ cell exhibits slight voltage hysteresis, which can be related to the voltage signature of the conversion-type anode (see Fig. S6 in the Supplementary Information). As compared with state of the art LIB systems, i.e., those based on graphite anode, $\mathrm{LiCoO}_{2}{ }^{[66]}$ and $\mathrm{LiFePO}_{4}{ }^{[67]}$ cathodes, and $\mathrm{Li}^{+-}$ insertion reaction, the voltage hysteresis evidenced by cells in which conversion redox process takes place (Fig. 6S) certainly represents an issue of to be solved. Considering the steady-state reversible capacity referred to the cathode mass (110 $\mathrm{mAh} \mathrm{g}^{-1}$, Fig. $\left.5 \mathrm{~d}\right)$ and the average working voltage (3.6 V, Fig. $5 \mathrm{c}$ ), we may estimate for the lithium-ion cell here reported a theoretical energy density of about $400 \mathrm{Wh} \mathrm{kg}^{-1}$. Taking into account the inactive material contribution, the cell may deliver a practical energy density of about $150 \mathrm{Wh} \mathrm{kg}^{-1}$, which is in line with the typical values expected by the common lithium-ion 
battery, ${ }^{[68]}$ with the additional bonuses represented by the use of new materials characterized by environmental compatibility, the easy synthetic pathway, and the expected low cost. A slight reduction of the overall cell operating voltage, especially upon discharge, can be observed by prolonged cycling (i.e. 90-100 cycles, Fig. 5c). This trend may be reasonably ascribed to the voltage profile variation of the ternary $\mathrm{CuO}-\mathrm{Fe}_{2} \mathrm{O}_{3}-\mathrm{MCMB}$ anode by cycling. Indeed, a slight increase of the $\mathrm{CuO}-\mathrm{Fe}_{2} \mathrm{O}_{3}-\mathrm{MCMB}$ anode discharge voltage profile can be observed upon cycling in lithium half cell (Fig. 3b), likely due to the electrode compositional, structural and microstructural modifications intrinsically associated with the conversion process, while minimal variation of the cathode voltage profile in lithium half-cell is exhibited (Fig. 5a). These evidences suggest that major contribution to the observed voltage profile of the full battery arise from the anode side. However, active material loss at the cathode side upon cycling cannot be completely excluded. This issues, associated to the modification of the electrode/electrolyte interface throughout full cell operation, ${ }^{[16]}$ may be actually addressed by further tuning the cell balance and the anode pre-lithiation procedure. In addition, we think that the study of $\mathrm{CuO}-\mathrm{Fe}_{2} \mathrm{O}_{3}-\mathrm{MCMB}$ electrochemical behaviour in lithium half- and full-cell, even if only a fraction of its capacity is used, may be of interest from an application perspective. Certainly, the lithium ion battery configuration herein presented is very preliminary, and requires further efforts in order to increase the anode utilization and its efficiency. However, it may be possibly presented for a series of applications such as the exploitation in battery operating at low temperatures, where the intercalating ability of conventional graphite anodes is suppressed, or in systems for which a high safety content is required, since the conversion anode material operates well fare from the lithium deposition reaction.

\section{Figure 5}

\section{Conclusion}


A new ternary, conversion-type $\mathrm{CuO}-\mathrm{Fe}_{2} \mathrm{O}_{3}-\mathrm{MCMB}$ anode was prepared through high-energy ball milling and fully characterized in terms of structure, morphology, and electrochemical behavior. The versatile synthesis pathway allowed the actual dispersion of the primary compounds and the formation of a composite material comprising nano and sub-micrometric oxides particles embedded into a carbon matrix, as shown by XRD, electron microscopy, and EDS. These structural and morphological characteristics reflected suitable electrochemical features for battery application, such as reversible

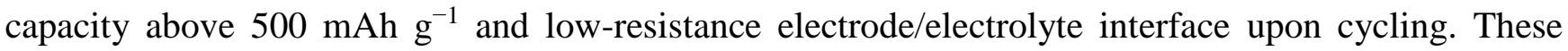
characteristics, in addition to proper features in terms of voltage profile, have allow the combination of the $\mathrm{CuO}-\mathrm{Fe}_{2} \mathrm{O}_{3}-\mathrm{MCMB}$ composite anode with high-voltage $\mathrm{Li}_{1.35} \mathrm{Ni}_{0.48} \mathrm{Fe}_{0.1} \mathrm{Mn}_{1.72} \mathrm{O}_{4}$ spinel cathode in highly efficient and stable full-cell. The $\mathrm{CuO}-\mathrm{Fe}_{2} \mathrm{O}_{3}-\mathrm{MCMB} / \mathrm{Li}_{1.35} \mathrm{Ni}_{0.48} \mathrm{Fe}_{0.1} \mathrm{Mn}_{1.72} \mathrm{O}_{4}$ cell revealed very promising performances at $1 \mathrm{C}$ rate, i.e., working voltage of about $3.6 \mathrm{~V}$, reversible capacity of about 110

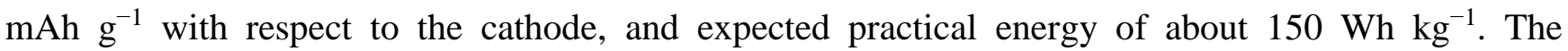
electrochemical behavior of the ternary composite anode reflects the characteristic redox properties of the employed $\mathrm{CuO}, \mathrm{Fe}_{2} \mathrm{O}_{3}$ and $\mathrm{MCMB}$ precursors in terms of operating voltage, delivered capacity, first cycle inefficiency, hysteresis and cycle life. The ternary anode exhibits higher delivered capacity, cycling stability, first cycle efficiency and rate capability than binary $\mathrm{CuO}-\mathrm{MCMB}$, which has been previously characterized by our group. ${ }^{[38]}$ As compared with binary $\mathrm{Fe}_{2} \mathrm{O}_{3}-\mathrm{MCMB},{ }^{[41]}$ the ternary anode shows similar electrochemical properties; however, the theoretical and practical capacities of the ternary composite are lower than the $\mathrm{Fe}_{2} \mathrm{O}_{3}$-MCMB one (with theoretical and practical capacity of 690 and 680 $\mathrm{mAh} \mathrm{g}^{-1}$, respectively), and its operating voltage is slightly higher than the one observed for $\mathrm{Fe}_{2} \mathrm{O}_{3^{-}}$ MCMB due to the presence of $\mathrm{CuO}$. The performances of the ternary anode in full cell configuration with the $\mathrm{Li}_{1.35} \mathrm{Ni}_{0.48} \mathrm{Fe}_{0.1} \mathrm{Mn}_{1.72} \mathrm{O}_{4}$ cathode are particularly attractive, as a remarkably stable capacity is delivered for 100 cycles, with Coulombic efficiency higher than $99 \%$ after 100 cycles. Therefore, the full cell characteristics of the ternary composite anode studied at a current density of about $150 \mathrm{~mA} \mathrm{~g}_{\text {cathode }}{ }^{-1}$ 
appear more appropriate in terms of cycling stability than the ones exhibited by binary $\mathrm{Fe}_{2} \mathrm{O}_{3}-\mathrm{MCMB}$ in the same cell configuration. ${ }^{[41]}$ Indeed, the full $\mathrm{Fe}_{2} \mathrm{O}_{3}-\mathrm{MCMB} / \mathrm{Li}_{1.35} \mathrm{Ni}_{0.48} \mathrm{Fe}_{0.1} \mathrm{Mn}_{1.72} \mathrm{O}_{4}$ battery previously

studied at a current density of $50 \mathrm{~mA}_{\text {cathode }}{ }^{-1}$ exhibited some capacity fade after 80 charge/discharge cycles, with capacity retention of $97 \%$ while the full cell presented in this work is characterized by a capacity retention approaching $100 \%$ for 100 cycles. In addition, the higher energy density in lithium half-cell of $\mathrm{Fe}_{2} \mathrm{O}_{3}-\mathrm{MCMB}$ with respect to $\mathrm{CuO}-\mathrm{Fe}_{2} \mathrm{O}_{3}-\mathrm{MCMB}$ due to the higher reversible capacity of the former is expected to be remarkably mitigated in full cell configuration. ${ }^{[1]}$ On the other hand, the cycling stability enhancement have strong effect on the performances of the lithium-ion battery. The advanced electrochemical performances observed for the ternary $\mathrm{CuO}-\mathrm{Fe}_{2} \mathrm{O}_{3}-\mathrm{MCMB}$ anode, especially in terms of cycling stability in lithium half- and full-cell, may be reasonably ascribed to its very stable electrode/electrolyte interface upon cycling which represent an additional advantage of the employed composite anode with respect to other binary materials reacting through conversion chemistry. Moreover, remarkable full cell voltage retention is achieved by combining the ternary $\mathrm{CuO}-\mathrm{Fe}_{2} \mathrm{O}_{3}-\mathrm{MCMB}$ anode with the $\mathrm{Li}_{1.35} \mathrm{Ni}_{0.48} \mathrm{Fe}_{0.1} \mathrm{Mn}_{1.72} \mathrm{O}_{4}$ cathode, which represents a fundamental step towards the development of high stability and long cycle life full batteries employing conversion-type anodes. Therefore, the cell configuration herein proposed has estimated energy density comparable to that of commercial battery, as well as intrinsic high environmental compatibility due to both the conversion-based anode and the Cofree cathode.

\section{Acknowledgements}

The work was performed within the collaboration project "Accordo di Collaborazione Quadro 2015" between the University of Ferrara (Department of Chemical and Pharmaceutical Sciences) and Sapienza University of Rome (Chemistry Department). The authors thank Daniela Palmeri (Electronic 
Microscopy Centre, Department of Chemical and Pharmaceutical Sciences, University of Ferrara) for performing SEM and TEM images.

\section{References}

[1] L. Croguennec, M. R. Palacin, J. Am. Chem. Soc. 2015, 137, 3140.

[2] J.-I. Lee, E.-H. Lee, J.-H. Park, S. Park, S.-Y. Lee, Adv. Energy Mater. 2014, 4, 1301542.

[3] Y. Wang, L. Yang, R. Hu, W. Sun, J. Liu, L. Ouyang, B. Yuan, H. Wang, M. Zhu, J. Power Sources 2015, 288, 314 .

[4] B. Deniz Polat, O. Levent Eryilmaz, Z. Chen, O. Keles, K. Amine, Nano Energy 2015, 13, 781.

[5] J. Ji, J. Liu, L. Lai, X. Zhao, Y. Zhen, J. Lin, Y. Zhu, H. Ji, L. L. Zhang, R. S. Ruoff, ACS Nano $2015,9,8609$.

[6] Y. Chen, Y. Li, Y. Wang, K. Fu, V. A. Danner, J. Dai, S. D. Lacey, Y. Yao, L. Hu, Nano Lett. 2016, acs. nanolett.6b02096.

[7] D. Liu, W. Zhu, J. Trottier, C. Gagnon, F. Barray, A. Guerfi, A. Mauger, H. Groult, C. M. Julien, J. B. Goodenough, K. Zaghib, RSC Adv. 2014, 4, 154.

[8] A. Kraytsberg, Y. Ein-Eli, Adv. Energy Mater. 2012, 2, 922.

[9] Y.-F. Deng, S.-X. Zhao, P.-Y. Zhai, G. Cao, C.-W. Nan, J. Mater. Chem. A 2015, 3, 20103.

[10] D. Di Lecce, R. Brescia, A. Scarpellini, M. Prato, J. Hassoun, ChemSusChem 2016, 9, 223.

[11] D. Andre, S. Kim, P. Lamp, F. Lux, F. Maglia, J. Mater. Chem. A Mater. energy Sustain. 2015, 3, 6709 .

[12] V. Aravindan, Y.-S. Lee, S. Madhavi, Adv. Energy Mater. 2015, 5, 1402225. 
[13] J. Hassoun, B. Scrosati, J. Electrochem. Soc. 2015, 162, A2582.

[14] N. Mahmood, T. Tang, Y. Hou, Adv. Energy Mater. 2016, 6, 1600374.

[15] B. Scrosati, J. Hassoun, Y.-K. Sun, Energy Environ. Sci. 2011, 4, 3287.

[16] J.-M. Tarascon, P. Poizot, S. Laruelle, S. Grugeon, L. Dupont, Nature 2000, 407, 496.

[17] S. Grugeon, S. Laruelle, L. Dupont, J.-M. Tarascon, Solid State Sci. 2003, 5, 895.

[18] Y. Wang, Q.-Z. Qin, J. Electrochem. Soc. 2002, 149, A873.

[19] X. Sun, C. Yan, Y. Chen, W. Si, J. Deng, S. Oswald, L. Liu, O. G. Schmidt, Adv. Energy Mater. 2014, 4, 1.

[20] Y. Sun, X. Hu, W. Luo, F. Xia, Y. Huang, Adv. Funct. Mater. 2013, 23, 2436.

[21] F. Hao, Z. Zhang, L. Yin, ACS Appl. Mater. Interfaces 2013, 5, 8337.

[22] L. Wang, W. Cheng, H. Gong, C. Wang, D. Wang, K. Tang, Y. Qian, J. Mater. Chem. 2012, 22, 11297.

[23] J. Hassoun, F. Croce, I. Hong, B. Scrosati, Electrochem. commun. 2011, 13, 228.

[24] J. Lian, X. Duan, J. Ma, P. Peng, T. Kim, W. Zheng, ACS Nano 2009, 3, 3749.

[25] H. Bin Wu, J. S. Chen, H. H. Hng, X. Wen (David) Lou, Nanoscale 2012, 4, 2526.

[26] A. Débart, L. Dupont, P. Poizot, J.-B. Leriche, J. M. Tarascon, J. Electrochem. Soc. 2001, 148, A1266.

[27] X. Wang, D.-M. Tang, H. Li, W. Yi, T. Zhai, Y. Bando, D. Golberg, Chem. Commun. 2012, $48,4812$.

[28] Q. Su, L. Yao, J. Zhang, G. Du, B. Xu, ACS Appl. Mater. Interfaces 2015, 7, 23062. 
[29] K. Chen, D. Xue, S. Komarneni, J. Power Sources 2015, 275, 136.

[30] D. Larcher, C. Masquelier, D. Bonnin, Y. Chabre, V. Masson, J.-B. Leriche, J.-M. Tarascon, J. Electrochem. Soc. 2003, 150, A133.

[31] Q. Su, D. Xie, J. Zhang, G. Du, B. Xu, ACS Nano 2013, 7, 9115.

[32] B. Tian, J. Światowska, V. Maurice, S. Zanna, A. Seyeux, L. H. Klein, P. Marcus, J. Phys. Chem. C 2013, 117, 21651.

[33] J. Cabana, L. Monconduit, D. Larcher, M. R. Palacín, Adv. Mater. 2010, 22, 170.

[34] A. Ponrouch, J. Cabana, R. Dugas, J. L. Slack, M. R. Palacín, RSC Adv. 2014, 4, 35988.

[35] F. Lin, D. Nordlund, T.-C. Weng, Y. Zhu, C. Ban, R. M. Richards, H. L. Xin, Nat. Commun. $2014,5,3358$.

[36] S. H. Yu, S. H. Lee, D. J. Lee, Y. E. Sung, T. Hyeon, Small 2016, 12, 2146.

[37] G. Chen, L. Yan, H. Luo, S. Guo, Adv. Mater. 2016, 7580.

[38] R. Verrelli, J. Hassoun, A. Farkas, T. Jacob, B. Scrosati, J. Mater. Chem. A 2013, 1, 15329.

[39] R. Verrelli, J. Hassoun, ChemElectroChem 2015, 2, 988.

[40] R. Verrelli, B. Scrosati, Y. Sun, J. Hassoun, ACS Appl. Mater. Interfaces 2014, 6, 5206.

[41] R. Verrelli, R. Brescia, A. Scarpellini, L. Manna, B. Scrosati, J. Hassoun, RSC Adv. 2014, 4, 61855.

[42] J.-H. Kim, N. P. W. Pieczonka, L. Yang, ChemPhysChem 2014, 15, 1940.

[43] J. Lu, C. Zhan, T. Wu, J. Wen, Y. Lei, A. J. Kropf, H. Wu, D. J. Miller, J. W. Elam, Y.-K. Sun, X. Qiu, K. Amine, Nat. Commun. 2014, 5, 5693. 
[44] D. W. Shin, C. A. Bridges, A. Huq, M. P. Paranthaman, A. Manthiram, Chem. Mater. 2012, 24, 3720.

[45] S. R. Li, C. H. Chen, J. R. Dahn, J. Electrochem. Soc. 2013, 160, A2166.

[46] Y.-P. Zeng, X. Wu, P. Mei, L.-N. Cong, C. Yao, R.-S. Wang, H.-M. Xie, L.-Q. Sun, Electrochim. Acta 2014, 138, 493.

[47] Y. Ein-Eli, J. T. Vaughey, M. M. Thackeray, S. Mukerjee, X. Q. Yang, J. McBreen, J. Electrochem. Soc. 1999, 146, 908.

[48] J. Liu, A. Manthiram, J. Phys. Chem. C 2009, 113, 15073.

[49] L. Lutterotti, Nucl. Instruments Methods Phys. Res. Sect. B Beam Interact. with Mater. Atoms 2010, 268, 334.

[50] B. A. Boukamp, Solid State Ionics 1986, 20, 31.

[51] R. Verrelli, J. Hassoun, J. Power Sources 2015, 299, 611.

[52] J. Hassoun, G. Derrien, S. Panero, B. Scrosati, Adv. Mater. 2008, 20, 3169.

[53] F. Jiao, J. Bao, P. G. Bruce, Electrochem. Solid-State Lett. 2007, 10, A264.

[54] C. Zhu, N. Sheng, T. Akiyama, RSC Adv. 2015, 5, 21066.

[55] M. Winter, J. O. Besenhard, M. E. Spahr, P. Novák, Adv. Mater. 1998, 10, 725.

[56] B. A. Boukamp, Solid State Ionics 1986, 20, 31.

[57] D. Aurbach, M. D. Levi, E. Levi, Solid State Ionics 2008, 179, 742.

[58] C. J. Wen, C. Ho, B. a. Boukamp, I. D. Raistrick, W. Weppner, R. a. Huggins, Int. Mater. Rev. $1981,26,253$. 
[59] C. Ho, I. D. Raistrick, R. A. Huggins, J. Electrochem. Soc. 1980, 127, 343.

[60] S. Zhang, M. S. Ding, K. Xu, J. Allen, T. R. Jow, Electrochem. Solid-State Lett. 2001, 4, A206.

[61] L. Martin, H. Martinez, D. Poinot, B. Pecquenard, F. Le Cras, J. Power Sources 2014, $248,861$.

[62] F. Klein, R. Pinedo, P. Hering, A. Polity, J. Janek, P. Adelhelm, J. Phys. Chem. C 2016, 120, 1400.

[63] B. Philippe, M. Valvo, F. Lindgren, H. Rensmo, K. Edström, Chem. Mater. 2014, 26, 5028.

[64] Y. Zeng, L. Li, H. Li, X. Huang, L. Chen, Ionics (Kiel). 2009, 15, 91.

[65] M. Gauthier, T. J. Carney, A. Grimaud, L. Giordano, N. Pour, H.-H. Chang, D. P. Fenning, S. F. Lux, O. Paschos, C. Bauer, F. Maglia, S. Lupart, P. Lamp, Y. Shao-Horn, J. Phys. Chem. Lett. 2015, $6,4653$.

[66] Z. Wang, Y. Fu, Z. Zhang, S. Yuan, K. Amine, V. Battaglia, G. Liu, J. Power Sources 2014, $260,57$.

[67] C. Fasciani, S. Panero, J. Hassoun, B. Scrosati, J. Power Sources 2015, 294, 180.

[68] M. M. Thackeray, C. Wolverton, E. D. Isaacs, Energy Environ. Sci. 2012, 5, 7854. 


\section{Table captions}

Table 1. Electrode/electrolyte interface resistances calculated by NLLS analysis of the EIS data of Fig. 4 using the equivalent circuit reported in Fig. S2 of the Supporting Information. $R_{\text {film }}=$ resistance of the SEI film; $\mathrm{R}_{\mathrm{ct}}=$ charge transfer resistance $; \mathrm{R}_{\mathrm{i}}=$ overall electrode/electrolyte interface resistance .

\section{Figure captions}

Figure 1. XRD patterns of the $\mathrm{CuO}-\mathrm{Fe}_{2} \mathrm{O}_{3}-\mathrm{MCMB}$ composite (black) and reference data of $\mathrm{CuO}$ (PDF \# 80-1916, grey bars), $\mathrm{Fe}_{2} \mathrm{O}_{3}$ (PDF \# 87-1165, blue bars), and graphite carbon (PDF \# 75-1621, yellow bars).

Figure 2. Electron microscopy analyses of the $\mathrm{CuO}-\mathrm{Fe}_{2} \mathrm{O}_{3}-\mathrm{MCMB}$ composite: (a) SEM images (magnification in inset); (b) SEM-EDS maps of $\mathrm{Cu}$ (blue), Fe (green), and $\mathrm{C}$ (red) over the sample powders (overlapped maps in the main panel; single maps in inset); (c, d) TEM images (magnification in inset).

Figure 3. Electrochemical characterization of the $\mathrm{CuO}-\mathrm{Fe}_{2} \mathrm{O}_{3}-\mathrm{MCMB}$ composite. (a) Cyclic voltammetry in three-electrode cell configuration with lithium disks as counter and reference electrode at scan rate of $0.01 \mathrm{mV} \mathrm{s}^{-1}$. (b) Galvanostatic cycling tests in lithium half-cell at $\mathrm{C} / 5$ rate in terms of (c) voltage profiles $\left(1^{\text {st }}\right.$ cycle in inset) and (c) cycling behavior (capacity on the left y-axis, coulombic efficiency on the right $\mathrm{y}$-axis). (d) Rate capability test in lithium half-cell at $\mathrm{C} / 5, \mathrm{C} / 3, \mathrm{C} / 2,1 \mathrm{C}, 2 \mathrm{C}$, and $5 \mathrm{C}$ rates. $1 \mathrm{C}=606 \mathrm{mAh} \mathrm{g}^{-1}$; test temperature $=23^{\circ} \mathrm{C}$.

Figure 4. Nyquist plots of EIS tests performed on three-electrode cells with lithium disks as counter electrode and lithium probe as reference electrodes at (a) open circuit voltage (OCV) condition and at the (b) $1^{\text {st }}$, (c) $10^{\text {th }}$, and (d) $50^{\text {th }}$ cycles of galvanostatic cycling at $\mathrm{C} / 5$ rate $\left(1 \mathrm{C}=606 \mathrm{mAh} \mathrm{g}^{-1}\right)$. 
Figure 5. (a-b) Galvanostatic cycling of the $\mathrm{Li}_{1.35} \mathrm{Ni}_{0.48} \mathrm{Fe}_{0.1} \mathrm{Mn}_{1.72} \mathrm{O}_{4}$ cathode in lithium half-cell at $1 \mathrm{C}$ rate $\left(148 \mathrm{mAh} \mathrm{g}^{-1}\right)$ in terms of (a) voltage profiles and (b) cycling behavior (capacity on the left y-axis, coulombic efficiency on the right $\mathrm{y}$-axis); (c-d) Galvanostatic cycling of the $\mathrm{CuO}_{-}-\mathrm{Fe}_{2} \mathrm{O}_{3}-$ $\mathrm{MCMB} / \mathrm{Li}_{1.35} \mathrm{Ni}_{0.48} \mathrm{Fe}_{0.1} \mathrm{Mn}_{1.72} \mathrm{O}_{4}$ full-cell at $1 \mathrm{C}$ rate with respect to the cathode mass $\left(148 \mathrm{mAh}_{\text {cathode }}{ }^{-1}\right)$ in terms of (c) voltage profiles and (d) cycling behavior (capacity on the left y-axis, coulombic efficiency on the right $\mathrm{y}$-axis); test temperature $=23^{\circ} \mathrm{C}$. 


\begin{tabular}{llll}
\hline Cycle & $\mathbf{R}_{\text {film }} / \mathbf{\Omega}$ & $\mathbf{R}_{\text {ct }} / \mathbf{\Omega}$ & $\mathbf{R}_{\mathbf{i}} / \mathbf{\Omega}$ \\
\hline OCV & - & - & $27.4 \pm 0.3$ \\
$1^{\text {st }}$ & $2 \pm 1$ & $12 \pm 2$ & $14 \pm 3$ \\
$10^{\text {th }}$ & $2.8 \pm 0.2$ & $7.9 \pm 0.2$ & $10.7 \pm 0.4$ \\
$50^{\text {th }}$ & $3.6 \pm 0.2$ & $8.2 \pm 0.3$ & $11.8 \pm 0.5$ \\
\hline
\end{tabular}

Table 1 


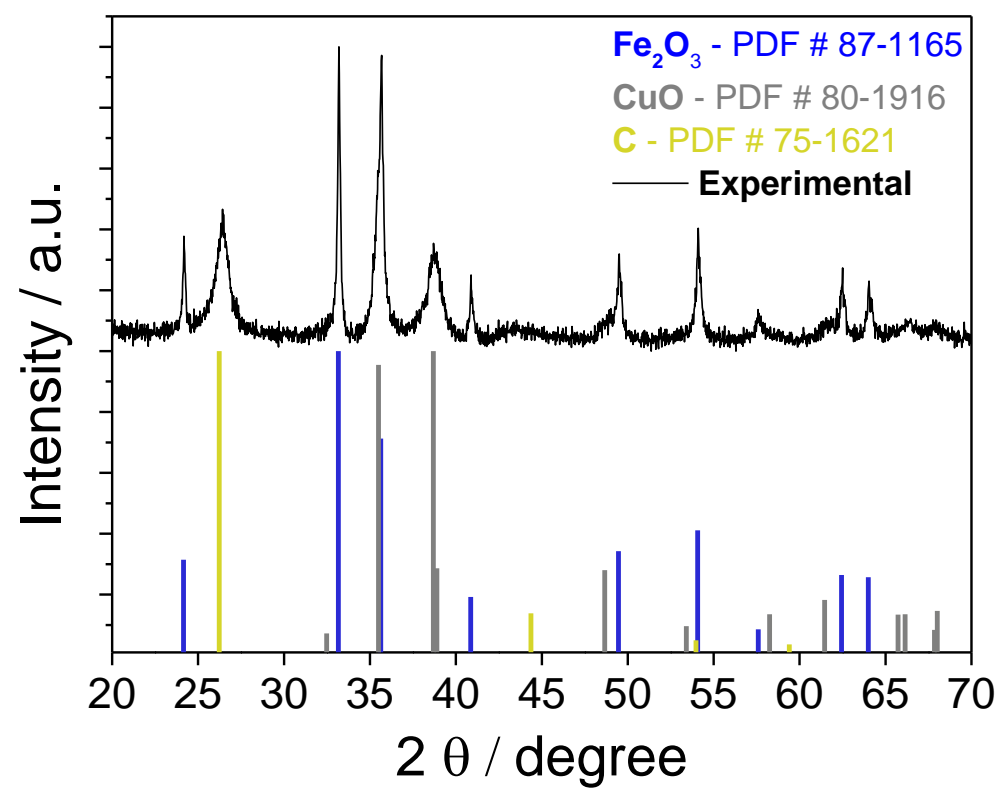

Figure 1 


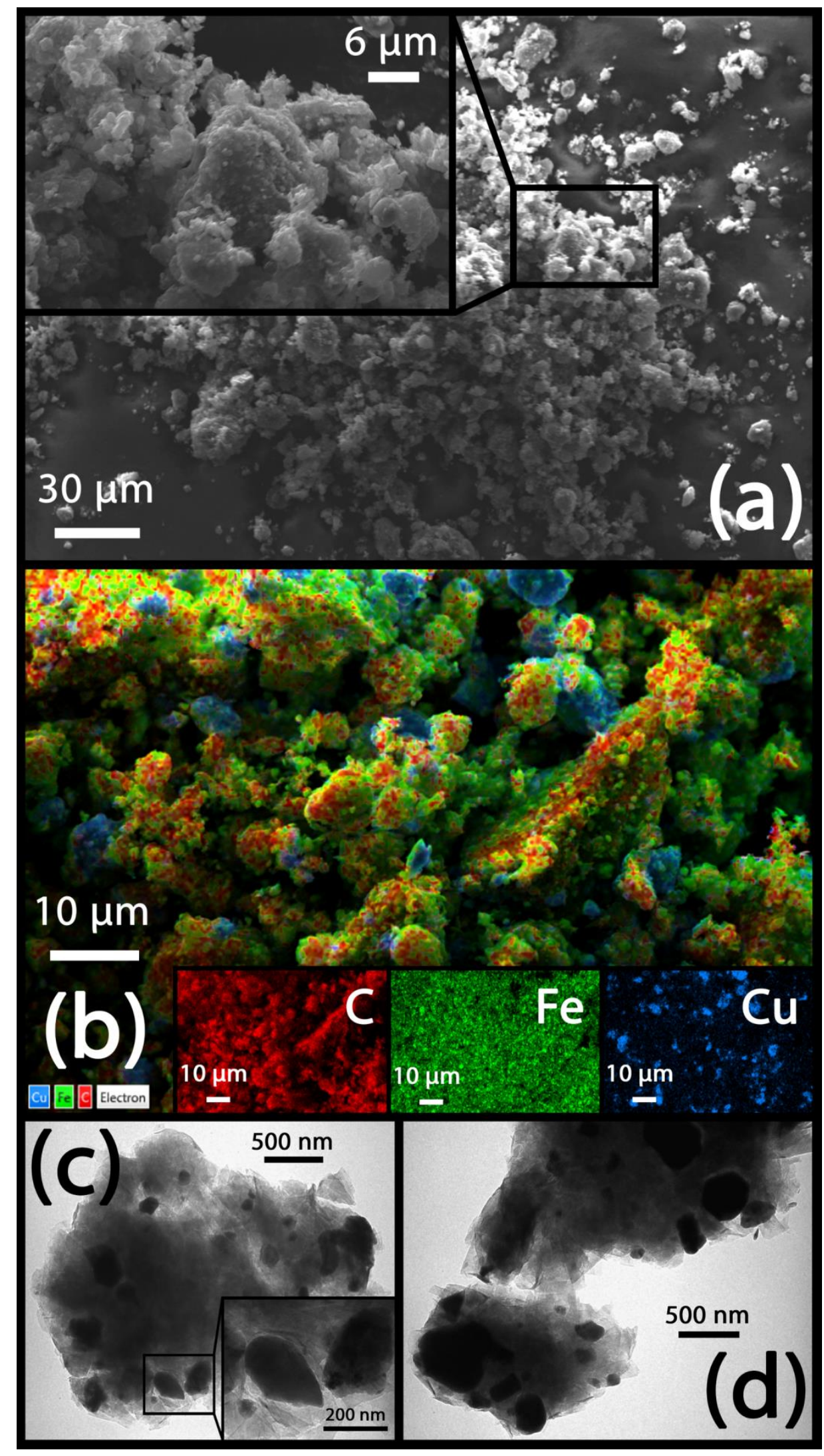

Figure 2 

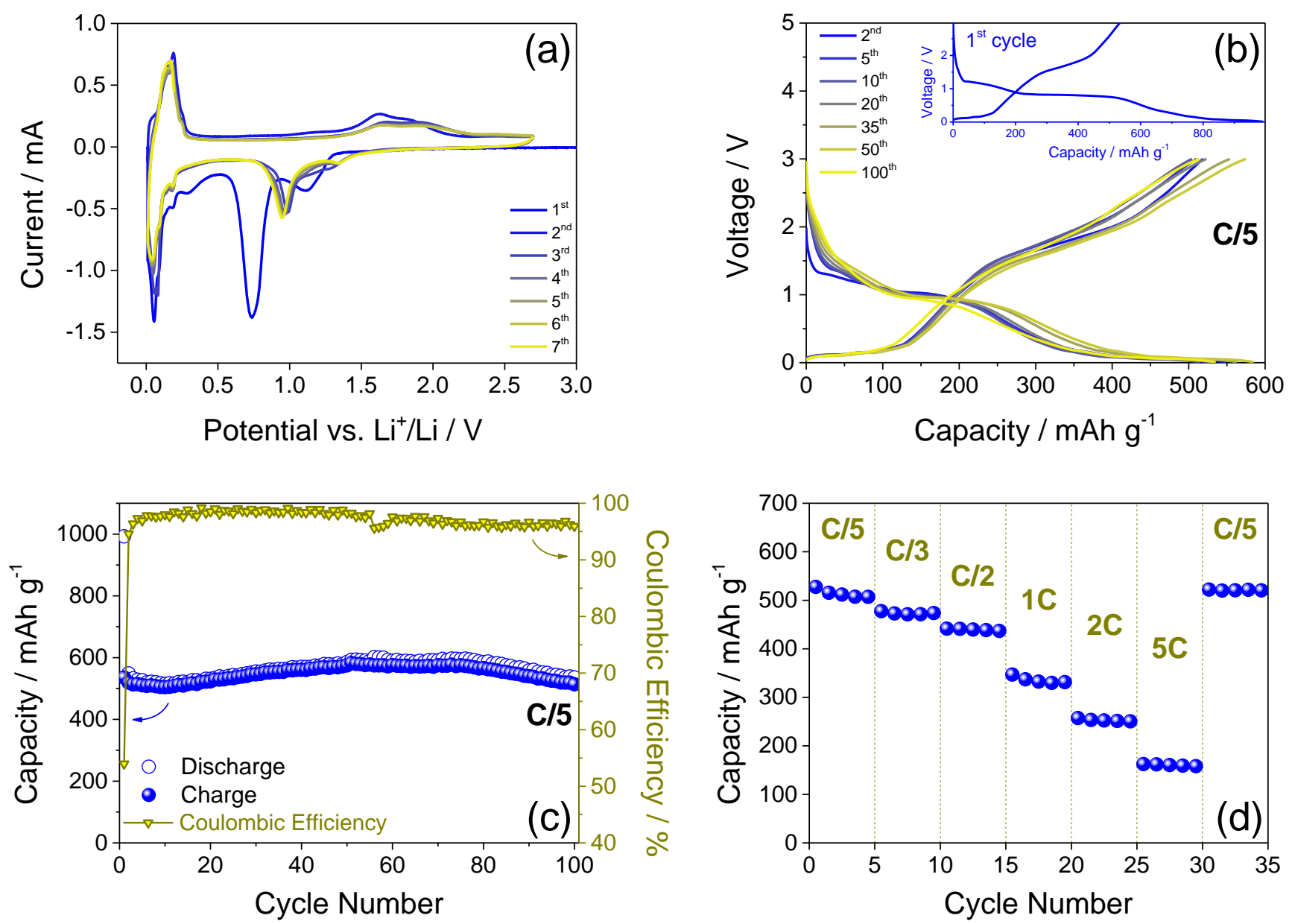

Figure 3 

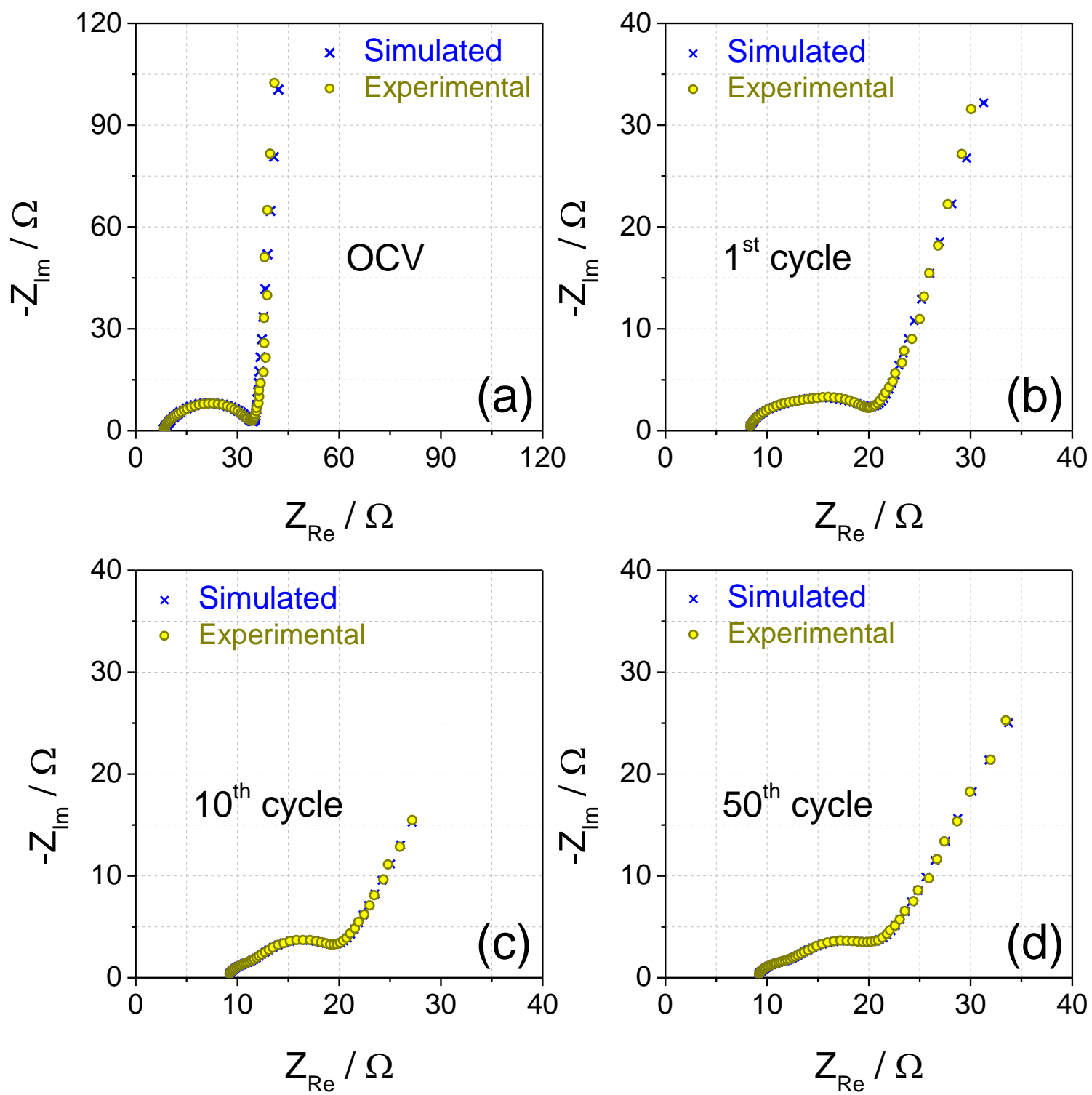

Figure 4 

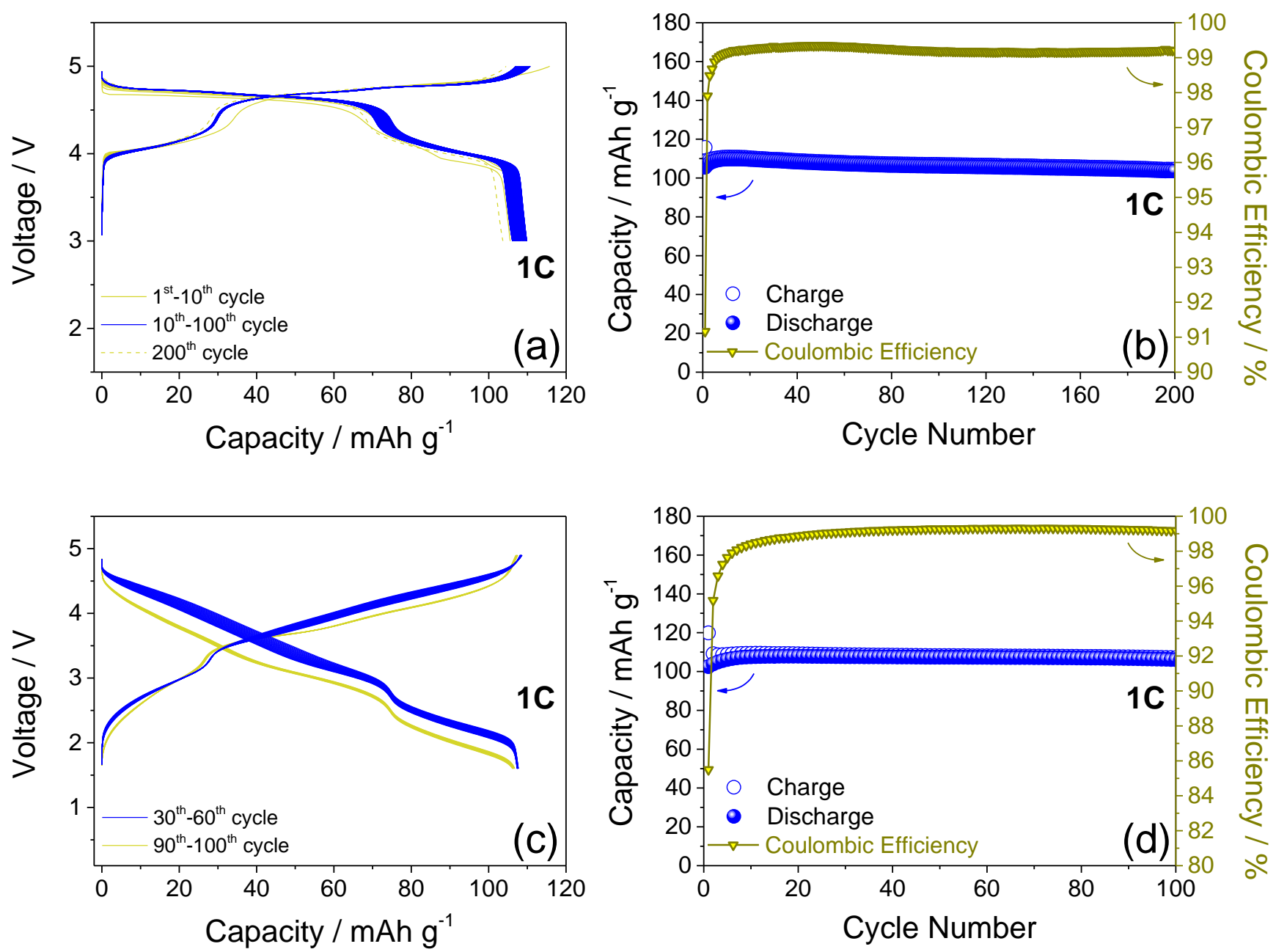

Figure 5 
Table of content image

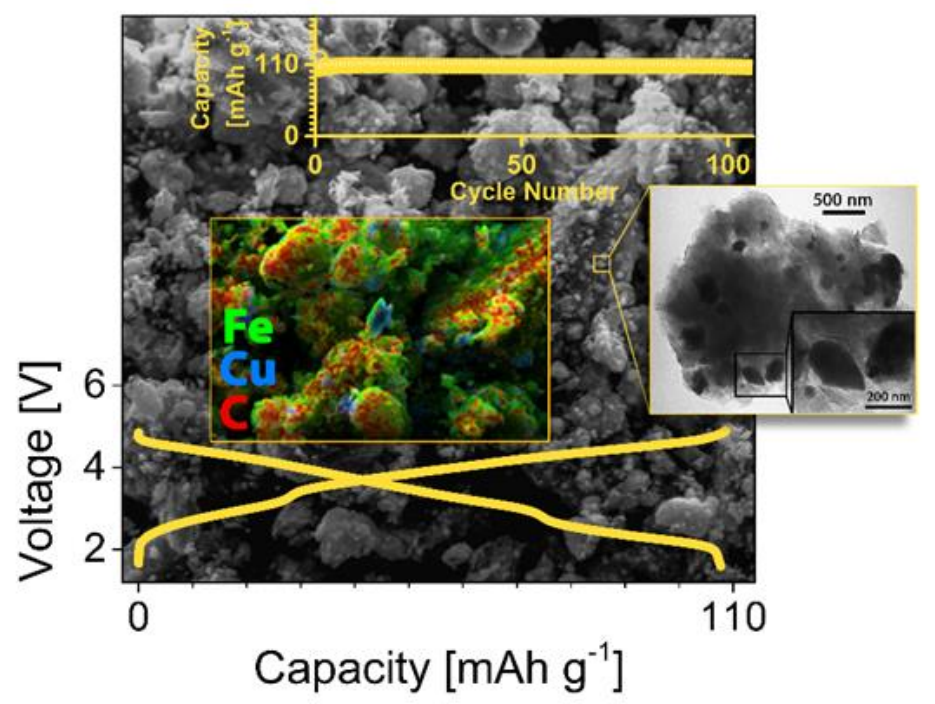

